\title{
云南省榕小蜂和榕树的物种组成及多样性
}

\author{
杨大荣 ${ }^{*}$ 徐 否 ${ }^{1,2}$ 彭艳琼 ${ }^{1,2}$ 魏作东 ${ }^{1,2} \quad \mathbf{E}^{-}$柱标 $^{1}$ \\ 1 (中国科学院西双版纳热带植物园, 昆明 650223) \\ 2 (中国科学院研究生院, 北京 100039)
}

\begin{abstract}
摘要: 榕小蜂是榕树 (Ficus spp.) 唯一的传粉昆虫, 榕树隐头果又是榕小蜂唯一的寄主。榕树必须依靠榕小蜂传粉 才能获得有性繁殖; 而榕小蜂又必须依靠榕树隐头果内的领花作为食物和栖息场所才能正常生长、发育和繁衍后 代, 因此两者间有着不可互缺的互惠共生关系, 二者缺一就面临着两类物种同时消亡和群落的灭绝。云南是中国 榕树和榕小蜂种类最丰富的省份。本文报道了在云南采集到的榕小蜂类群, 隶属 12 属 50 种。云南的榕树和榕小 蜂主要分布在热带和南亚热带地区的河谷和海拔 $1600 \mathrm{~m}$ 以下区域。随着海拔的升高, 两类物种数量随之减少, 到 了海拔 $3700 \mathrm{~m}$ 以上地区, 除了人工种植外, 已无自然分布的榕树种群。榕小蜂的个体数量、物种丰富度、多样性指 数都是在滇南地区热带雨林内最高, 滇西北的高山峡谷区最低。
\end{abstract}

关键词: 物种多样性, 分布, 互惠共生,Ficus, 榕小蜂

中图分类号: Q948.12+2.5 文献标识码: A 文章编号: 1005-0094(2004)06-0611-07

\section{Species composition and diversity of fig wasps and figs in Yunnan}

\author{
YANG Da-Rong $^{1 *}$, XU Lei ${ }^{1,2}$, PENG Yan-Qiong ${ }^{1,2}$, WEI Zuo-Dong ${ }^{1,2}$, DUAN Zhu-Biao ${ }^{1}$ \\ 1 Xishuangbanna Tropical Botanical Garden, Chinese Academy of Sciences, Kunming 650223 \\ 2 Graduate School of the Chinese Academy of Sciences, Beijing 100039
}

\begin{abstract}
Hymenoptera of the family Agaonidae (fig wasps) are the obligate pollinating insects of fig trees (Ficus spp. ), and fig syconium is the only host of fig wasp. For the pollination of their flowers, fig trees are dependent upon fig wasps. For their reproduction and growth, fig wasps are dependent upon the gall (ovaries) of the figs, in which their larvae develop. Thus, the two groups share a symbiotic relationship. Species diversity and richness of fig and fig wasp are highest in Yunnan among all the provinces of China. Our study shows that the fig wasps collected from Yunnan include 50 species of 12 genera, which are mainly distributed in the tropics and south sub-tropics below an altitude of $1600 \mathrm{~m}$. Both figs and fig wasps decrease in species number with increasing altitude. Above an altitude of $3700 \mathrm{~m}$, no natural fig tress were found, except for cultivated species. Species diversity increased in the following order: northwestern Yunnan $\left(H^{\prime}=0.6902\right)$, northeastern Yunnan $\left(H^{\prime}=0.6976\right)$, central Yunnan $\left(H^{\prime}=0\right.$. $9211)$, southeastern Yunnan $\left(H^{\prime}=1.2164\right)$, western Yunnan $\left(H^{\prime}=1.5017\right)$, and southern Yunnan $\left(H^{\prime}=1.6441\right)$.
\end{abstract}

Key words: fig wasp, Ficus, species diversity, distribution, mutualism

全世界约有榕树 750 种, 主要分布在热带和南 亚热带地区, 是热带雨林中最大的木本属之一, 也是 热带雨林地区关键植物类群之一（Berg，1989， 1992; Janzen, 1979a, b; 许再富, 1994; Weiblen, 2002 )。榕树只有依靠榕小蜂传粉才能完成有性繁 殖, 榕小蜂是榕树唯一的传粉昆虫。榕树是桑科
(Moraceae)、榕属 (Ficus) 中全部树种的总称。榕属 植物的特征为: 有乳汁; 托叶大而抱茎脱落后在节上 留有环痕。花单性, 生于由花序托发育而成的肉质 球型或梨形内壁上, 称隐头花序果 (简称隐头果) 或 无花果。果实大小不同, 果内小花的数量也存在着 非常明显的差异:一个隐头果内少则有数十朵小花, 
多则 4-5 万朵。

在中国, 已经记载有榕树 100 多种, 主要分布在 云南、贵州、海南、广东、广西、台湾、西藏等省 (区), 其中种类最丰富的是云南省。吴征镒在《云南植物 志》中报道有 67 种 (吴征镒, 1995 ); 张秀实和吴征 镒在《中国植物志》中报道云南分布榕树 71 种, 占 全国榕树总种数的 $70 \%$ (张秀实等, 1998)。然而, 有关云南的榕树传粉昆虫榕小蜂的报道却非常少, 除作者等报道过西双版纳地区分布的 17 种外, 未见 其他报道 (谷海燕和杨大荣, 2003; 徐否等, 2003 ; 杨 大荣等, 1997, 1999, 2000, 2001, 2002a，b，2003a， b)。1999-2004 年, 作者等在云南各地连续进行了 5 年考察, 又采集到 40 多种榕树和 30 多种榕小蜂 标本, 结合以前采集到的榕树和榕小蜂标本, 现整理 报道如下。

\section{1 研究区域自然概况}

云南省 $\left(21^{\circ} 9^{\prime}-29^{\circ} 15^{\prime} \mathrm{N}, 97^{\circ} 39^{\prime}-106^{\circ} 12^{\prime} \mathrm{E}\right)$ 位于我国西南边陲, 总面积约 39 万 $\mathrm{km}^{2}$, 占我国国 土总面积的 $4.2 \%$ 。东西跨距约 $885 \mathrm{~km}$, 南北幅度 约 $910 \mathrm{~km}$ 。基本上属于低纬度地带的内陆地区, 是 我国显著的高原地貌省份之一。

从云南整体来看, 东部为云贵高原的西半部; 西 部系青藏高原的南延部分, 是青藏高原东部的横断 山脉核心地区, 为怒江 (萨尔温江上游)、澜沧江( 湄 公河上游)、金沙江 (长江上游) 切割的高山峡谷地 形; 北高南低, 自西北向东南倾斜, 其斜面之陡为我 国罕见，坡度可达 $0.6 \%$ 。滇西北的梅里雪山主峰

卡格博峰, 海拔达 $6740 \mathrm{~m}$; 滇东南河口境内与 南溪河交汇处海拔仅有 $76.4 \mathrm{~m}$ 。由于出现高纬度 高海拔, 低纬度低海拔的空间结构, 直接加剧了南北 地表热量和水分组合的明显差异, 形成了 8 个明显 的气候带类型: 北热带、南亚热带、中亚热带、北亚热 带、暖温带、温带、寒温带和高山苔原及雪山冰漠带; 因而也导致了榕树和榕小蜂的分布从南至北出现了 明显的地带性规律。

\section{2 研究方法}

\section{1 采集地分区}

根据对云南不同地区、不同榕树种类的结果期 与特性的长期观察, 参照《云南植物志》第六卷 (吴 征镒, 1995) 中桑科榕属的种类、分布和生物学特
性, 从 1999 年起在云南以下 6 个区域内开展了采集 与考察: 滇南区 (包括西双版纳州、思茅地区、临沧 地区，简称 YS) 、滇东南区 (红河州、文山州, YSE)、 滇中区 ( 昆明市、玉溪市、楚雄州，YC) 、滇西区（保 山市、大理州、德宏州，YW）、滇西北区(丽江地区、 迪庆州、怒江州, YNW)、滇东北区(曲靖市、昭通地 区, YEN)。

\section{2 采集方法}

在每一地区分布的榕树隐头果接近成熟时, 每 种榕树采集不少于 5 个样点, 每个样点采集量不少 于 100 个隐头果。每一株榕树采集时不少于 30 个 隐头果, 少于 30 个隐头果的榕树全部采集。把采集 到的隐头果放入用 120 篎目的绢纱网缝制成的 10 $\mathrm{cm} \times 15 \mathrm{~cm}$ 的口袋中, 每一株榕树采集的隐头果单 独放入一个绢纱袋中, 让榕小蜂自然羽化出蜂。每 个袋中放入标注采集树种、时间、地点、海拔和采集 人的标签, 同时详细记录采集榕树分布地生态特征。

待隐头果内榕小蜂完全羽化后, 收集果内外所 有小蜂, 解剖和计数果腔未出蜂的瑤花。将这些小 蜂放在 $75 \%$ 的酒精中保存, 标明采集的时间和地 点, 带回实验室内, 借助 Olympus ( SZX12-3141) 体视 显微镜和 DP50(580 万像素)数码相机, 对收集到的 榕小蜂进行形态拍照, 然后根据种类和性别对它们 进行分拣、计数、分类鉴定,统计种类和数量。

2.3 数据处理方法

物种多样性分析采用 Shannon-Wiener 多样性指 数 (Shannon \& Wiener, 1949):

$$
H^{\prime}=-\sum_{i=1}^{S} P_{i} \ln P_{i}
$$

$P_{i}=n_{i} / N, P_{i}$ 为第 $i$ 种占总个体数 $N$ 的比例, $S$ 代表 物种数。

均匀度采用 Pielou 指数 (Pielou, 1975):

$J=H^{\prime} / H_{\text {max }}\left(H_{\text {max }}=\ln S\right)$

物种优势度采用 Berger-Parker 指数 (Berger \& Parker, 1970 ):

$$
D=N / N_{t}
$$

$N$ 为优势种的种群数量之和, $N$ 为全部物种的种群 数量之和。

\section{3 结果与分析}

\section{1 云南已采集到的榕树和榕小蜂种类}

经过多年的采集与考察, 作者等在云南全省共 
采集到榕树 65 种; 采到成熟隐头果内的榕小蜂 58 种, 其中已经鉴定到属种的榕小蜂 12 属 50 种, 共获 榕小蜂标本 156 万多号( 见表 1 )。

目前全国报道有榕树 101 种, 云南就有 71 种; 其次是贵州省, 仅报道有 42 种 (张秀实等, 1998 )。 目前本文作者等在云南就已采集到 65 种,而且各种 生长类型的榕树种类均已采集到。如果按榕树和榕 小蜂一对一来估测 (极少数有例外), 目前已经采集 到的榕树和榕小蜂种类已经分别超过全国分布总种 数的 $64 \%$ 和 $57 \%$, 说明云南分布的物种非常丰富。

此外, 榕小蜂在榕树隐头果内的生活类型也是 丰富多样:生活在雌雄同株榕树中的有 26 种, 在雌 雄异株的榕树中 22 种。其中, 有 38 种榕小蜂是生 活在榕树枝顶叶腋间挂果的隐头果内; 有 7 种是生 活在老茎挂果的隐头果内; 有 2 种是同时生活在老 茎无叶枝和叶腋挂果的隐头果内; 有 1 种是生活在 地表或土内无叶枝隐头果内 (表 1 )。

\section{2 榕小蜂和榕树的水平分布}

榕小蜂和其寄主榕树在云南分布很广, 几乎全 省所有县(市)均可发现。从水平分布来看, 滇南区 (YS) 的榕小蜂的属、种均最为丰富, 已经采集到的 云南分布的所有属在该地区均有分布, 种类高达 50 种，占已经鉴定总种类的 $100 \%$; 其次是滇东南区域 ( YSE) 和滇西区 $(Y W)$, 分别达 11 属 38 种和 35 种, 分别占已经鉴定总种类的 $74 \%$ 和 $70 \%$; 再次是滇 中区 $(\mathrm{YC})$, 采集到 5 属 12 种，占已经鉴定总种类 的 $24 \%$; 滇西北区 ( YNW ) 和滇东北区 $(\mathrm{YEN})$ 分布 最少, 分别是 5 属 9 种和 8 种, 分别占已经鉴定总 种类的 $18 \%$ 和 $16 \%$ 。结果见表 2 。

\section{3 榕树和榕小蜂的垂直分布}

云南地处低纬度地区, 由于云贵高原和青藏高 原东部的横断山脉影响, 榕小蜂和榕树具有非常明 显的垂直分布特性。云南 $70 \%$ 的榕小蜂和榕树种 类分布在滇南、滇西和滇东南的热带地区; 其次是南 亚热带地区; 再次分别是亚热带、北亚热带地区和干 热河谷区; 在温带地区有零星种类分布; 而寒温带地 区则罕有分布。

从海拔上看: 榕小蜂和榕树主要分布在海拔 $1500 \mathrm{~m}$ 以下地区, 特别是海拔 $500-750 \mathrm{~m}$ 的区域 分布最为丰富。随着海拔升高, 榕小蜂和寄主树数 量下降, 到了海拔 $3500 \mathrm{~m}$, 除了大果爬藤榕 (Ficus sarmentosa var. duclouxii)、珍珠榕（F. sarmentosa var. henryii)等少数藤本、半藤本榕树种类外, 已经 罕见分布( 见图 1)。

\section{4 物种多样性分析}

用物种个体数量、多样性指数、均匀度指数、优 势度指数等指标定量比较不同地区榕小蜂群落结构 特征, 结果见表 3 。

从云南全省来看: 物种丰富度、个体数量、多样性 指数、均匀度指数均以滇南区最高, 其次是滇东南, 再 次是滇西, 然后是滇中、滇东北和滇西北。滇西北物 种数超过滇东北, 但多样性指数和均匀度指数却比后 者低。原因是在滇西北的怒江峡谷和澜沧江峡谷出 现一些如木瓜榕( Ficus auriculata)、苹果榕( F. oligodon) 等大果类榕树, 这些种类的一个单果内榕小蜂 数量就高达成千上万, 特别明显地高于其他种类, 致 使多样性指数和均匀度指数降低。在全省, 榕小蜂优 势种群出现无规律的状态, 这也是与一些地区大果 类、中型果类榕树物种较多,而另一些地区大果类和 中型果类榕树物种少或者无分布形成的。

\section{4 讨论}

在云南省共采集到 58 种榕小蜂和 65 种寄主榕 树, 已经鉴定出榕小蜂种类 50 种, 隶属 12 个属, 占 全国已经报道的榕小蜂种类的 $90 \%$, 证明云南是中 国榕小蜂和寄主榕树种类最丰富的省份。由于榕小 蜂寄生在榕树隐头果㾉花内, 当隐头果成熟时榕小 蜂才从㾉花内羽化出来, 才能采集到成虫, 所以采集 该类昆虫有一定的困难。虽然采到 65 种寄主榕树, 但由于未能完全采集到接近成熟又未出蜂的隐头 果, 所以采到的榕小蜂种类相对比榕树种类少。这 也是全世界发表榕树种类多, 而发表传粉昆虫榕小 蜂种类少的主要原因之一( Wiebes, 1979)。

榕树和榕小蜂的绝大部分种是两者共同进化的 结果。它们为了互相适应而在形态特征、化学物质、 生态特性上协同进化, 这方面的研究报道近年来逐 渐增多 (Anstett et al. ，1997; Barker，1985；马炜梁 等, 1997; 宋启示等, 2001)。但我们在云南的采集 中, 也发现了同一株榕树有两种传粉榕小蜂的情况, 如高山榕隐头果内的 Eupristina altissma 和 Eupristi$n a \mathrm{sp} .1$ 和细叶榕隐头果内的 Eupristina verticillata 和 Walkerella microcarpae。这 2 种榕树的榕小蜂为 何又未遵循一对一的规律, 是什么因素造成的? 种榕树出现两种传粉榕小蜂, 哪一种为主要传粉者? 
表 1 云南榕小蜂和榕树种类及生活特性(1997-2003 年)

Table 1 Bio-ecological characteristics of the figs and fig wasps in Yunnan ( 1997 - 2003 )

\begin{tabular}{|c|c|c|c|}
\hline $\begin{array}{l}\text { 榕小蜂种类 } \\
\text { Fig wasp species }\end{array}$ & $\begin{array}{l}\text { 寄主榕树种类 } \\
\text { Fig species }\end{array}$ & $\begin{array}{l}\text { 隐头果着生部位 } \\
\text { Growing place for syconium }\end{array}$ & $\begin{array}{l}\text { 榕树性别 } \\
\text { Sex of figs }\end{array}$ \\
\hline Blastophaga ishnopoda & 壸托榕 Ficus ischnopoda & 叶腋挂果 In the leaf axil & 雌雄异株 Dioecism \\
\hline B. javana hilli & 粗叶榕 F. hirta & 叶腋挂果 In the leaf axil & 雌雄异株 Dioecism \\
\hline B. javana javana & 全缘粗叶榕 F. hirta var. brevipita & 叶腋挂果 In the leaf axil & 雌雄异株 Dioecism \\
\hline B. medusa & 纸叶榕 F. chartacea & 叶腋挂果 In the leaf axil & 雌雄异株 Dioecism \\
\hline B. nipponica & 矮小天仙果 $F$. erecta & 叶腋挂果 In the leaf axil & 雌雄异株 Dioecism \\
\hline Blastophaga sp. 1 & 青藤公 F. langkokensis & 叶腋挂果 In the leaf axil & 雌雄异株 Dioecism \\
\hline Blastophaga sp. 2 & 竹叶榕 F. stenophylla & 叶腋挂果 In the leaf axil & 雌雄异株 Dioecism \\
\hline Blastophaga sp. 3 & 歪叶榕 F. cyrtophylla & $\begin{array}{l}\text { 叶腋和老茎挂果 } \\
\text { In the leaf axil and on spurs on the older wood }\end{array}$ & 雌雄异株 Dioecism \\
\hline Ceratosolen fusciceps & 聚果榕 $F$. racemosa & 老茎挂果 On spurs on the older wood & 雌雄同株 Androgyne \\
\hline C. solmsi marchali & 对叶榕 F. hispida & $\begin{array}{l}\text { 老茎和叶腋挂果 } \\
\text { In the leaf axil and on spurs on the older wood }\end{array}$ & 雌雄异株 Dioecism \\
\hline C. gravelyi & 鸡嗉果 $F$. semicordata & 老茎挂果 On spurs on the older wood & 雌雄异株 Dioecism \\
\hline C. probaly & 平枝榕 $F$. prostrata & $\begin{array}{l}\text { 根部无叶枝挂果 } \\
\text { On leafless branchlets on the root }\end{array}$ & 雌雄异株 Dioecism \\
\hline C. appendiculatus & 青果榕 $F$. variegata var. chlorocarpa & 老茎挂果 On spurs on the older wood & 雌雄异株 Dioecism \\
\hline C. constrictus hewitti & 水同木 $F$. fistulosa & 老茎挂果 On spurs on the older wood & 雌雄异株 Dioecism \\
\hline Ceratosolen sp. & 肉托榕 $F$. squamosa & 老茎挂果 On spurs on the older wood & 雌雄异株 Dioecism \\
\hline Deliagaon annulatae & 环纹榕 $F$. annulata & 叶腋挂果 In the leaf axil & 雌雄同株 Androgyne \\
\hline Dolichoris malabarensis & 厚皮榕 F. callosa & 叶腋挂果 In the leaf axil & 雌雄同株 Androgyne \\
\hline E. emeryi & 垂叶榕 F. benjamina & 叶腋挂果 In the leaf axil & 雌雄同株 Androgyne \\
\hline E. koningsbergeri & 丛毛垂叶榕 F. benjamina var. nuda & 叶腋挂果 In the leaf axil & 雌雄同株 Androgyne \\
\hline E. curtipes & 针叶榕 F. curtipes & 叶腋挂果 In the leaf axil & 雌雄同株 Androgyne \\
\hline E. verticillata & 细叶榕 F. microcarpa & 叶腋挂果 In the leaf axil & 雌雄同株 Androgyne \\
\hline E. hookeriana & 大青树 F. hookeriana & 叶腋挂果 In the leaf axil & 雌雄同株 Androgyne \\
\hline E. orthoncura & 直脉榕 $F$. orthoneura & 叶腋挂果 In the leaf axil & 雌雄同株 Androgyne \\
\hline E. aqundersi & 心叶榕 F. rumphii & 叶腋挂果 In the leaf axil & 雌雄同株 Androgyne \\
\hline E. cyclostigma & 劲直榕 $F$. stricta & 叶腋挂果 In the leaf axil & 雌雄同株 Androgyne \\
\hline Liporrhopalum gibbosae & 斜叶榕 F. tinctoria ssp. gibosa & 叶腋挂果 In the leaf axil & 雌雄异株 Dioecism \\
\hline L. subulatae & 假斜叶榕 F. subulata & 叶腋挂果 In the leaf axil & 雌雄异株 Dioecism \\
\hline Platsyscapa concinna & 雅榕 F. concinna & 叶腋挂果 In the leaf axil & 雌雄同株 Androgyne \\
\hline Platsyscapa sp. & 无柄雅榕 $F$. concinna var. subsessilis & 叶腋挂果 In the leaf axil & 雌雄同株 Androgyne \\
\hline P. quadraticeps & 菩提树 $F$. religiosa & 叶腋挂果 In the leaf axil & 雌雄同株 Androgyne \\
\hline P. corneri & 华丽榕 $F$. superba & 叶腋挂果 In the leaf axil & 雌雄同株 Androgyne \\
\hline P. coronata & 绿黄葛树 $F$. virens & 叶腋挂果 In the leaf axil & 雌雄同株 Androgyne \\
\hline P. sahiana & 黄葛树 $F$. virens var. sublanceolata & 叶腋挂果 In the leaf axil & 雌雄同株 Androgyne \\
\hline P. paschimaghatensis & 曲枝榕 $F$. geniculata & 叶腋挂果 In the leaf axil & 雌雄同株 Androgyne \\
\hline Philotrypesis ficicola & 山榕 $F$. heterophylla & 叶腋挂果 In the leaf axil & 雌雄异株 Dioecism \\
\hline Walkerella microcarpae & 细叶榕 F. microcarpa & 叶腋挂果 In the leaf axil & 雌雄同株 Androgyne \\
\hline Waterstoniella williamsi & 大叶水榕 $F$. glaberrima & 叶腋挂果 In the leaf axil & 雌雄同株 Androgyne \\
\hline Watshamiella infida & 龙州榕 $F$. cardiophylla & 叶腋挂果 In the leaf axil & 雌雄同株 Androgyne \\
\hline
\end{tabular}


表 2 云南省不同区域榕小蜂的属和种的分布比较( $1997-2003$ 年)

Table 2 No. of genus and species of fig wasps in different areas in Yunnan (1997 - 2003)

\begin{tabular}{|c|c|c|c|c|c|c|}
\hline \multirow[b]{2}{*}{$\begin{array}{c}\text { 榕小蜂属 } \\
\text { Fig wasp genus }\end{array}$} & \multicolumn{6}{|c|}{ 种数 No. of species } \\
\hline & $\begin{array}{c}\text { 滇南 } \\
\text { Southern } \\
\text { Yunnan }\end{array}$ & $\begin{array}{c}\text { 滇西 } \\
\text { Western } \\
\text { Yunnan }\end{array}$ & $\begin{array}{c}\text { 滇东南 } \\
\text { Southeastern } \\
\text { Yunnan }\end{array}$ & $\begin{array}{c}\text { 滇中 } \\
\text { Central } \\
\text { Yunnan }\end{array}$ & $\begin{array}{c}\text { 滇西北 } \\
\text { Northwestern } \\
\text { Yunnan }\end{array}$ & $\begin{array}{c}\text { 滇东北 } \\
\text { Northeastern } \\
\text { Yunnan }\end{array}$ \\
\hline Deliagaon & 1 & 1 & 1 & 0 & 0 & 0 \\
\hline Platsyscapa & 7 & 5 & 4 & 3 & 3 & 3 \\
\hline Dolichoris & 4 & 1 & 2 & 0 & 0 & 0 \\
\hline Ceratosolen & 10 & 7 & 8 & 3 & 2 & 1 \\
\hline Blastophaga & 9 & 7 & 9 & 2 & 2 & 2 \\
\hline Wiebesia & 2 & 1 & 2 & 1 & 1 & 1 \\
\hline Liporrhopalum & 2 & 1 & 2 & 0 & 0 & 0 \\
\hline
\end{tabular}

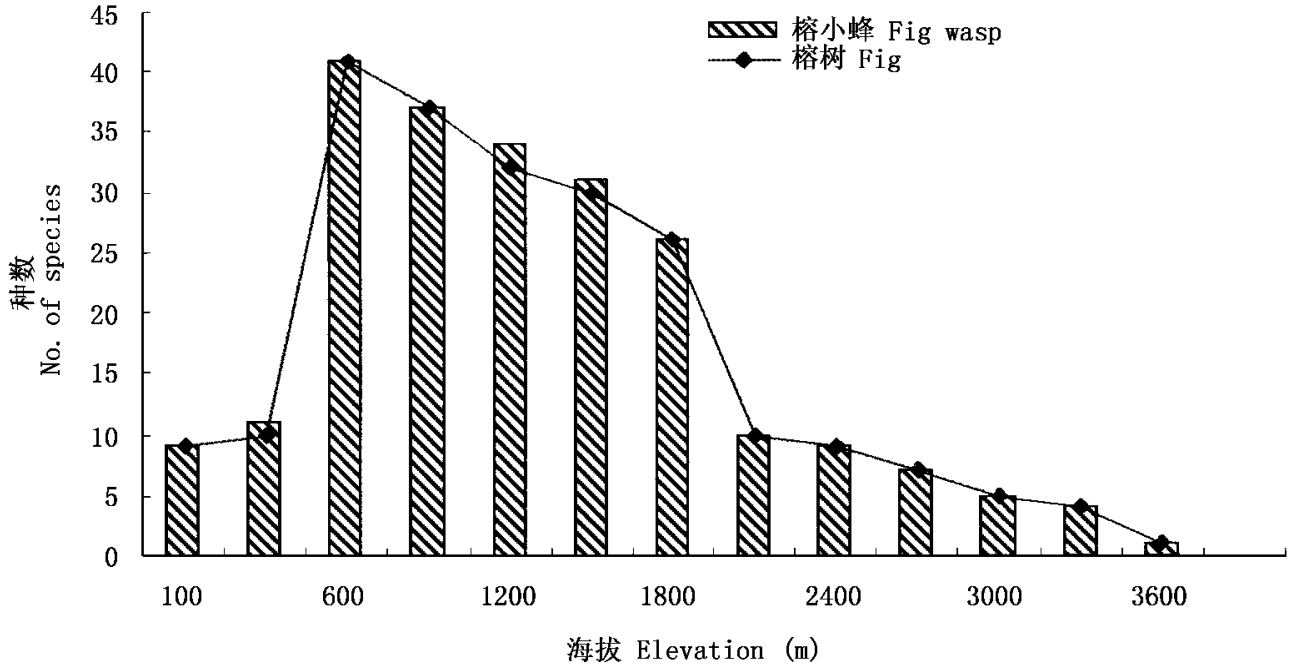

图 1 云南省不 同海拔榕树和榕 小蜂种类分布比 较

Fig. 1 Comparisons of figs and fig wasp species at different elevations in Yunnan

表 3 云南省不同区域的榕小蜂物种多样性比较

Table 3 Species diversity of fig wasps in different areas in Yunnan

\begin{tabular}{|c|c|c|c|c|c|c|}
\hline & $\begin{array}{c}\text { 滇南 } \\
\text { Southern } \\
\text { Yunnan }\end{array}$ & $\begin{array}{c}\text { 滇东南 } \\
\text { Southeastern } \\
\text { Yunnan }\end{array}$ & $\begin{array}{c}\text { 滇西 } \\
\text { Western } \\
\text { Yunnan }\end{array}$ & $\begin{array}{c}\text { 滇中 } \\
\text { Central } \\
\text { Yunnan }\end{array}$ & $\begin{array}{c}\text { 滇西北 } \\
\text { Northwestern } \\
\text { Yunnan }\end{array}$ & $\begin{array}{c}\text { 滇东北 } \\
\text { Northeastern } \\
\text { Yunnan }\end{array}$ \\
\hline $\begin{array}{l}\text { 物种丰富度 }(S) \\
\text { Species richness }\end{array}$ & 50 & 37 & 35 & 12 & 9 & 8 \\
\hline $\begin{array}{l}\text { 个体数量 }(N) \\
\text { No. of individuals }\end{array}$ & 612197 & 397261 & 360169 & 109786 & 44880 & 41031 \\
\hline $\begin{array}{l}\text { 均匀度指数 }(J) \\
\text { Evenness index }\end{array}$ & 0.4225 & 0.4191 & 0.3450 & 0.3707 & 0.3141 & 0.3355 \\
\hline $\begin{array}{l}\text { 优势度指数 }(D) \\
\text { Dominance index }\end{array}$ & 0.3878 & 0.4167 & 0.3235 & 0.3333 & 0.2222 & 0.2500 \\
\hline
\end{tabular}


它们对隐头果内的繁殖资源是如何分配的? 这些机 制有待于今后深入试验和研究。

榕树为了物种的正常繁衍而将雌雄同株上的短 柱花以及雌雄异株上的雄株隐头果内的全部小花给 榕小蜂繁殖, 从而换取了榕小蜂在雌雄同株的隐头果 内为大部分长柱花传粉, 仅在部分短柱花上产卵繁 殖; 榕小蜂在雌雄异株的雌株榕树隐头果内给全部的 小花传粉, 由于这些小花全部是长柱花, 榕小蜂不能 产卵繁殖, 授完粉后, 榕小蜂在果腔内死亡。榕树和 其传粉者榕小蜂二者皆有所失, 但最终目的是共有所 得, 使两个物种得到持续繁衍。所以, 榕小蜂和寄主 榕树要繁殖成功, 必须在森林生态系统中不断繁衍种 群, 但是, 人类活动使许多榕树生长的地区, 如热带雨 林地区、热带地区、南亚热带地区的生态环境不断恶 化, 森林片断化、岛屿化, 许多榕树形成孤独植株, 严 重地制约了榕小蜂有效地传粉, 使榕树失去了有性繁 殖的能力, 从而导致两类生物不能互惠共生而逐渐消 亡。所以保护和恢复以森林生态系统为主的生态环 境, 也就有效地保护了榕小蜂和寄主榕树这两类互惠 共生关系最密切的生物。

致谢: 法国榕小蜂分类专家 J-Y Rasplus 提供国外的 榕小蜂分类资料; 中国科学院西双版纳热带植物园朱 宏先生, 云南白药集团赵庭周和尹辅相先生, 四川省 资源研究所谷海燕女士等采集并提供了部分榕小蜂 标本, 在此表示感谢。

\section{参考文献}

Anstett, M. C. , Hossaert-McKey M. and Kjellberg, F. 1997.

Figs and fig pollinators: evolutionary conflicts in a coevolved mutualism. Trends in Ecology and Evolution, 12:94 - 99.

Barker, N. P. 1985. Evidence of a volatile attractant in Ficus ingens (Moraceae). Bothalia, 15:607 -611.

Berg, C. C. 1989. Classification and distribution of Ficus. Experientia, 45: $606-611$.

Berg, C. C. and Wiebes, J. T. 1992. African Fig Trees and Fig Wasps. Koninklijke Nederlandse Akademie van Wetenschappen, Amsterdam, $1-298$.

Berger, W. H. and Parker, F. L. 1970. Diversity of planktonic foraminifera on deep-sea sediments. Science, 168: 1345 1347.

Chang, S. S. (张秀实) and Wu, C. Y. (吴征镒). 1998. Flora Reipublicae Popularis Sinicae (中国植物志). Tomus 23(1). Science Press, Beijing, $91-219$. (in Chinese)
Gu, H. Y. (谷海燕) and Yang, D. R. (杨大荣) . 2003. Community structure and species diversity of fig wasps from Ficus altissima. Biodiversity Science (生物多样性), 11: 188 - 196. (in Chinese with English abstract)

Janzen, D. H. 1979a. How many parents do the wasps from a fig have? Biotropica, 11: 127 - 129.

Janzen, D. H. 1979b. How to be a fig? Annual Review of Ecology and Systematics, 10: $13-51$.

Ma, W. L. (马炜梁), Chen, Y. (陈勇) and Li, H. Q. (李宏 庆). 1997. A summarize of the study on fig trees and its pollinators. Acta Ecologica Sinica (生态学报), 17: 209 215. (in Chinese with English abstract)

Pielou, E. C. 1975. Mathematical Ecology. John Wiley \& Sons, New York.

Shannon, C. E. and Wiener, W. 1949. The Mathematical Theory of Communication. University of Illinois Press, Illinois, 117.

Song, Q. S., Yang, D. R. and Zhang, G. M. 2001. Volatiles from Ficus hispida and its attraction to fig wasps. Journal of Chemical Ecology, 27: 1929 - 1942.

Weiblen, G. D. 2002. How to be a fig wasp? Annual Review of Entomology, 47: 299 - 330 .

Wiebes, J. T. 1979. Co-evolution of figs and their insect pollinators. Annual Review of Ecology and Systematics, 10: 1 - 12 .

Wu, C. Y. (吴征镒). 1995. Flora of Yunnan (云南植物志). Vol.6. Science Press, Beijing, 595-671. (in Chinese)

$\mathrm{Xu}$, L. (徐否), Yang, D. R. (杨大荣), Peng, Y. Q. (彭艳 琼), Wang, Q. Y. (王秋艳) and Zhang, G. M. (张光明). 2003. The community structure and the interspecific relationship of the fig wasps in syconia of Ficus racemosa L. in Xishuangbanna, China. Acta Ecologica Sinica(生态学报), 23: 1554 - 1560. ( in Chinese with English abstract)

Xu, Z. F. (许再富). 1994. Ficus - a keystone plant species in the tropical rain forest ecosystem of south Yunnan. Chinese Biodiversity (生物多样性), 2:21 - 23. (in Chinese)

Yang, D. R. (杨大荣)，Li， C. D. (李朝达) and Yang, B. (杨 兵). 1997. Studies on animal structure and biodiversity on Ficus in the tropical rainforest of Xishuangbanna, China. Zoological Research(动物学研究), 18:189-196. (in Chinese with English abstract)

Yang，D. R. (杨大荣)，Li，C. D. (李朝达) and Han，D. B. (韩 灯保). 1999. The effects of fragmenting of tropical rainforest on the species structure of fig wasps and fig trees, China. Zoological Research(动物学研究), 20:126-130. (in Chinese with English abstract)

Yang, D. R. (杨大荣), Wang, R. W. (王瑞武), Song, Q. S. (宋启示) and Zhang, G. M. (张光明). 2000. Rule of seasonal changes of the Ceratosolen sp. in the tropical rainforest of Xishuangbanna, China. Forest Research (林业科学研 
究), 13:477 -484. (in Chinese with English abstract) Yang, D. R. (杨大荣), Zhao, T. Z. (赵庭周), Wang, R. W. (王瑞武), Zhang, G. M. (张光明) and Song, Q. S. (宋启 示). 2001. Studies of pollination ecology of fig wasp (Ceratosolen sp. ) in the tropical rainforest of Xishuangbanna, China. Zoological Research(动物学研究), 22: 131 - 139. (in Chinese with English abstract)

Yang, D. R., Peng, Y. Q., Song, Q. S., Zhang, G. M., Wang, R. W., Zhao, T.Z. and Wang, Q. Y. 2002a. Pollination biology of Ficus hispida in the tropical rainforests of Xishuangbanna, China. Acta Botanica Sinica (植物学报), 44: $519-526$.

Yang, D. R. (杨大荣), Peng, Y. Q. (彭艳琼), Zhang, G. M. (张光明), Song, Q. S. (宋启示), Zhao, T. Z. (赵庭周) and Wang, Q. Y. (王秋艳). 2002b. Relationship between population variation of fig trees and environment in the tropi- cal rainforests of Xishuangbanna. Environmental Science (环 境科学), 23: 29-35. (in Chinese with English abstract) Yang, D. R. (杨大荣), Peng, Y. Q. (彭艳琼), Wang, Q. Y. (王秋艳), Xu, L. (徐否) and Wei, Z. D. (魏作东). 2003a. The structure of insect communities and the ecological characteristics of the functional groups in syconia of three fig trees species in Xishuangbanna, China. Acta Ecologica Sinica(生态学报), 23: 1798 - 1806. (in Chinese with English abstract)

Yang, D. R. (杨大荣), Peng, Y. Q. (彭䎦琼), Zhang, G. M. (张光明), Song, Q. S. (宋启示), Zhao, T. Z. (赵庭周) and Wang, Q. Y. (王秋艳). 2003b. Structure and biodiversity of insect community on syconia fruits of Ficus racemosa in tropical rainforest of Xishuangbanna, China. Chinese Journal of Applied Ecology(应用生态学报), 14: 1710 1714. (in Chinese with English abstract) 